Original Contribution

\title{
KARYOLOGICAL AND MORPHOLOGICAL VARIATIONS WITHIN BLITUM VIRGATUM L. (CHENOPODIACEAE) IN BULGARIA
}

\author{
N. Grozeva ${ }^{1}$, Y. Cvetanova ${ }^{2}$ \\ ${ }^{1}$ Department of Biology and Aquaculture, Faculty of Agriculture, Trakia University, Stara Zagora, \\ Bulgaria \\ ${ }^{2}$ Enrolment Services, University Registrar, University of Toronto, Toronto, Canada
}

\begin{abstract}
Eight populations of Blitum virgatum L., belonging to 5 different phytogeographic regions have been karyologically and morphologically tested. Intrapopulation and interpopulation variability have been traced. The relationship between morphological and karyological variability, ecological, and geographic appurtenance of the studied populations has been explored. The main source of phenotype variation in all population is the interpopulation variation. Interpopulation differences are influenced by the differences in karyotypes, environmental conditions and composition of communities.
\end{abstract}

Key words: Blitum virgatum, karyology, morphology, variation.

\section{INTRODUCTION}

Blitum virgatum $\mathrm{L}$. is usually easy to recognize because of its red, berry-like glomerules. However, its depauperate plants and lateseason branches may have dry, non-succulent glomerules. The species is widespread in Europe (the mountainous regions of Central and Northern Europe, parts of South and Eastern Europe incl. Balkan Peninsula); Asia Minor; North America; North and South Africa (1- 4). In Bulgaria Blitum virgatum is spread in the Balkan Range, Sofia region, West Frontier Mts, Mt Belasitsa, Mt Slavyanka, Pirin Mts, Rila Mt, Mt Sredna Gora, Rhodope Mts, Tracian Lowland, Tundzha Hilly Country (1, $5)$.

The decoction of its aerial parts has been used for treatment of sensitive gums and pimples (6), as antioxidant (7), diuretic (8) etc. The species has been recognized by Bulgarian legislation (9) as a medicinal plant, therefore its biologically active substances have been examined $(10,11)$. The Bulgarian populations of the species have not been subject of comprehensive research until now. Karyological research has been conducted.

\footnotetext{
* Correspondence to: $N$. Grozeva, Faculty of Agriculture, Trakia University, Stara Zagora, Bulgaria,grozeva@uni-sz.bg
}

Van Loon \& Van Setten (12) report diploid chromosome number $2 n=18$ for Blitum virgatum from the Central Balkan Range, Grozeva \& Stoeva (13) confirm this chromosome number for the populations from Western Rhodope Mts and Tundza Hilly Country.

The aim of this study was to investigate the patterns and levels of karyological and morphological variation, as well as ecological conditions of the natural local Bulgarian populations of Blitum virgatum.

\section{MATERIALS AND METHODS}

Karyologycal and morphological analyses were carried out for 8 natural Bulgarian populations of Blitum virgatum (Table 1).

The karyotype characteristics have been based on metaphase plates obtained from root tops of seeds germinating in laboratory conditions. The roots were treated and squashed according to the accepted methods (14). The chromosomal type was determined after the centromere index $\mathrm{I}=\mathrm{s} / \mathrm{s}+1$, according to the classification proposed by Grif \& Agapova (15). Five metaphase plates have been measured from each population. The voucher specimens are kept in the herbarium of the Bulgarian Academy of Sciences (SOM). 
GROZEVA N., et al.

Table 1. Studied populations of Blitum virgatum L. *data published by Grozeva \& Stoeva (13)

\begin{tabular}{|c|c|c|c|c|}
\hline $\begin{array}{l}\text { Population } \\
\text { number }\end{array}$ & $2 n$ & Locality & Ecological conditions & Structure, number, area \\
\hline 77 & $18^{*}$ & $\begin{array}{l}\text { Central Balkan range, } \\
\text { town of Kalofer, } 50 \\
\mathrm{~m} \text { far from the road } \\
\text { to Karlovo. }\end{array}$ & $\begin{array}{l}\text { Flat terrain, a soil type - } \\
\text { Cambisols, alt. } 666 \mathrm{~m} \text {, ruderal } \\
\text { community dominated by } \\
\text { Agrostis canina L. }\end{array}$ & $\begin{array}{l}\text { Diffuse spatial structure, } \\
\text { number }-45 \text { specimens, } \\
\text { area }-130 \mathrm{~m}^{2} \text {. }\end{array}$ \\
\hline 78 & 18 & $\begin{array}{l}\text { The Rila Mt., town of } \\
\text { Blagoevgrad, near } \\
\text { garbage bins in the } \\
\text { east side of the city. }\end{array}$ & $\begin{array}{l}\text { Flat terrain, a soil type - Luvisols, } \\
\text { alt. } 360 \mathrm{~m} \text {, ruderal community } \\
\text { dominated by Urtica dioica L. }\end{array}$ & $\begin{array}{l}\text { Diffuse spatial structure, } \\
\text { number }-50 \text { specimens, } \\
\text { area }-180 \mathrm{~m}^{2} \text {. }\end{array}$ \\
\hline 116 & $18^{*}$ & $\begin{array}{l}\text { Western Rhodope } \\
\text { Mts., Beglica hut, } \\
\text { pasture. }\end{array}$ & $\begin{array}{l}\text { Slightly sloped terrain facing } \\
\text { south-east, a soil type - } \\
\text { Cambisols, alt. } 1500 \mathrm{~m} \text {, ruderal } \\
\text { community dominated by } \\
\text { Agropyron repens (L.) P.Beauv. } \\
\text { and Urtica dioica. }\end{array}$ & $\begin{array}{l}\text { Mosaic spatial structure, } \\
\text { number - } 500 \text { specimens, } \\
\text { area - } 2,5 \text { dka. }\end{array}$ \\
\hline 118 & 18 & $\begin{array}{l}\text { Western Rhodope } \\
\text { Mts., town of Batak, } \\
\text { on the streets and } \\
\text { near the houses. }\end{array}$ & $\begin{array}{l}\text { Slightly sloped terrain facing } \\
\text { west, a soil type - Luvisols, alt. } \\
1036 \text { m, ruderal community } \\
\text { dominated by Capsella bursa- } \\
\text { pastoris (L.) Medik and } \\
\text { Agropyron repens. }\end{array}$ & $\begin{array}{l}\text { Mosaic spatial structure, } \\
\text { number }-43 \text { specimens, } \\
\text { area }-90 \mathrm{~m}^{2}\end{array}$ \\
\hline 119 & 18 & $\begin{array}{l}\text { Central Rhodope } \\
\text { Mts., Bachkovo - } \\
\text { above the monastery. }\end{array}$ & $\begin{array}{l}\text { Slightly sloped terrain, a soil type } \\
\text { - Cambisols, alt. } 932 \mathrm{~m} \text {, ruderal } \\
\text { community dominated by } \\
\text { Parietaria officinalis L. and } \\
\text { Urtica dioica. }\end{array}$ & $\begin{array}{l}\text { Diffuse spatial structure, } \\
\text { number }-60 \text { specimens, } \\
\text { area }-270 \mathrm{~m}^{2} .\end{array}$ \\
\hline 117 & 18 & $\begin{array}{l}\text { Belasitsa Mt., town } \\
\text { of Petrich, areas near } \\
\text { garbage bins. }\end{array}$ & $\begin{array}{l}\text { Flat terrain, a soil type - Alluvial, } \\
\text { alt. } 168 \mathrm{~m} \text {, ruderal community } \\
\text { dominated by Urtica dioica. }\end{array}$ & $\begin{array}{l}\text { Diffuse spatial structure, } \\
\text { number }-85 \text { specimens, } \\
\text { area }-40 \mathrm{~m}^{2}\end{array}$ \\
\hline 120 & 18 & $\begin{array}{l}\text { Tundzha Hilly } \\
\text { Country, between } \\
\text { Dunavtsi village and } \\
\text { TPP "Maritsa East - } \\
\text { 2". }\end{array}$ & $\begin{array}{l}\text { Flat terrain, a soil type - Luvisols, } \\
\text { alt. } 300 \mathrm{~m} \text {, ruderal community } \\
\text { dominated by Setaria viridis (L.) } \\
\text { P.Beauv. and Amaranthus } \\
\text { retroflexus L. }\end{array}$ & $\begin{array}{l}\text { Mosaic spatial structure, } \\
\text { number }-300 \text { specimens, } \\
\text { area }-580 \mathrm{~m}^{2} .\end{array}$ \\
\hline 37 & $18^{*}$ & $\begin{array}{l}\text { Tundzha Hilly } \\
\text { Country, Golyam } \\
\text { manastir village, in } \\
\text { the east side of the } \\
\text { village near pits. }\end{array}$ & $\begin{array}{l}\text { Flat terrain, a soil type - Luvisols, } \\
\text { alt. } 213 \mathrm{~m} \text {, ruderal community } \\
\text { dominated by Datura stramonium } \\
\text { L. and Solanum nigrum L. }\end{array}$ & $\begin{array}{l}\text { Mosaic spatial structure, } \\
\text { number }-70 \text { specimens, } \\
\text { area }-130 \mathrm{~m}^{2} .\end{array}$ \\
\hline
\end{tabular}

The morphological analysis comprises 24 quantitative characters reported in 30 specimens of each population: 1. plant height; 2. basal leaf length; 3. basal leaf width; 4 . length/width ratio; 5 . basal leaf petiole length; 6. upper leaf length; 7. upper leaf width; 8 . length/width ratio; 9. upper leaf petiole length; 10. inflorescence length; 11. flower petiole length; 12. flower diameter; 13. perianth lobes length of bisexual flower; 14. perianth lobes width of bisexual flower; 15 . perianth lobes length of female flower; 16. perianth lobes width of female flower; 17. seed length; 18 . seed width; 19. length/width ratio; 20. seed thickness; 21. fruit length; 22. fruit width; 23. length/width ratio; 24 . fruit thickness. The morphological data have been processed by the program StatSoft Statistica 12. The population means and the coefficients of variation $(\mathrm{CV}$ in $\%$ ) have been estimated for each character of each population. Their values have been used for comparison of various characters within the populations and between the populations. The Cluster analysis (CA) has been applied for exploration of the hierarchical classification of the populations using the Unweighted PairGroup Average (UWPGA) algorithm. Euclidean distance (ED) in the multivariate set of all morphological characters has been used as a measure of similarity between the populations. The one-way ANOVA method has been applied to determine the relative share of intra- and interpopulation variability. 
For a more detailed study of the morphology of generative organs, the Scanning Electron Microscope method has been used. The electron microscope tests have been conducted at the laboratory of the Faculty of Chemistry and Pharmacy at Sofia University.

\section{RESULTS AND DISCUSSION Karyology}

For all populations diploid chromosome number $2 n=18$ has been established (Table 1). This number confirms the findings for Bulgaria of Van Loon \& Van Setten (12) and Grozeva \& Stoeva (13) and is in accordance with the data by Kawatani \& Ohno (16) from Japan; Fedorov (17) and Magulaev (18) from the former USSR; Dvořák \& al. (19) from the Czech Republic; Schwarzova (20) from Slovakia; Lomonosova \& Krasnikov (21) and Krasnikov (22) from Russia; Lomonosova \& al. (23) from Kazakhstan.

The karyotypes of six of the studied populations $(116,118,119,37,120,117)$ consist of 8 pairs metacentric and 1 pair submetacentric chromosomes (Figure 1A, B).
The karyotype of the 3 populations from Rhodope Mts. - 116 from Beglika area, 118 from Batak and 119 from Bachkovo, differs from that of the rest by the existence of satellites in one of the metacentric chromosome pairs and in a submetacentric chromosome pair (Figure 1, A). In the other 3 populations - 37 from Tundzha Hilly Country, Golyam Manastir, 120 from Tundzha Hilly Country, Dunavsti, and 117 from Belasitsa Mt., Petrich, presence of satellites is observed only in one of the metacentric chromosome pairs (Figure 1, B). The longest chromosomes in all populations have the length between 3.95 and $4.29 \mu \mathrm{m}$ and are submetacentric. The shortest chromosomes have the length between 1.53 and $1.78 \mu \mathrm{m}$ and are metacentric. The length of total chromosomes of the populations is between 46.6 and $53.38 \mu \mathrm{m}$.

The karyotypes of the other 2 studied populations - 77 from Central Balkan Range, Kalofer and 78 from Rila Mt, Blagoevgrad consists of 7 pairs metacentric and 2 pair submetacentric chromosomes (Figure 1, C).

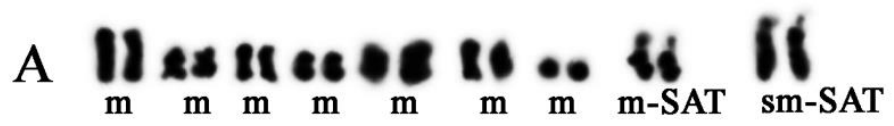

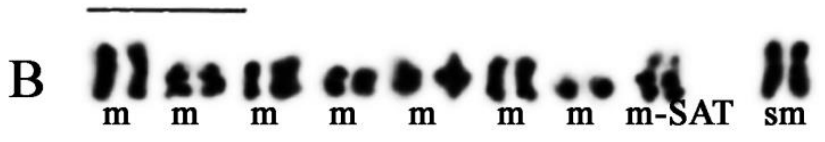

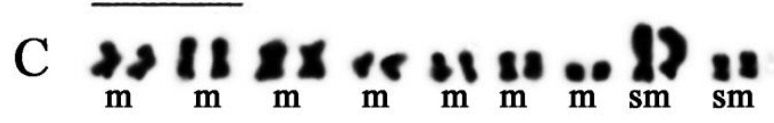

Figure 1. Karyograms of Blitum virgatum, 2n=18: A-population 119 from Central Rhodope Mts.; B-population 120 from Tundzha Hilly Country; C-population 78 from The Rila Mt.

\begin{abstract}
Morphology
In each of the studied populations the vegetative traits have higher level of variability than the generative (Table 2). The most variable traits for all populations are the following: basal leaf petiole length $(19.35 \% \leq$ $\mathrm{CV} \leq 35.29 \%)$; inflorescence length $(20.02 \% \leq$ $\mathrm{CV} \leq 32.69 \%)$; basal leaf width $(16.8 \% \leq \mathrm{CV}$ $\leq 34.27 \%)$. The most conservative are: fruit $(5.45 \% \leq \mathrm{CV} \leq 9.49 \%)$ and seed $(6.02 \% \leq \mathrm{CV}$ $\leq 11.88 \%)$ length, fruit width $(6 \% \leq \mathrm{CV} \leq$ $11.21 \%)$ and fruit thickness $(6.43 \% \leq \mathrm{CV} \leq$ $13.31 \%)$. The lowest coefficients of variation have been found for the flower, seed and fruit
\end{abstract}

quantitative characteristics of the population 77 from the Central Balkan Range.

It has not been established variability in the quality attributes characterizing generative organs. The perianth is bright green, becoming red, enlarged, and fleshy in fruit. The perianth segments (3-5), usually in the upper parts, are 5-membered and in the base are 3-4membered; glabrous, entire, not killed, connate below the middle with obtuse apex (Figure 3, A). The pericarp has a highly folded, laminated structure with a total thickness of 1.5-2.5 $\mu \mathrm{m}$ and the thickness of each of the layers is 0.5$0.7 \mu \mathrm{m}$; it is difficult to separate the pericarp 
GROZEVA N., et al.

from the seed surface (Figure 3, B-C). The seeds are vertical, oval to slightly elongated, dark red-brown (Figure 3, D-E). The seed margin is broad and blunt; the embryonic root is slightly convex, both sides of the seed are almost identical, with sculptural coverage in the form of obscure lines, concaves and bumps (Figures 3, D-F).

Table 2. Mean (first line) and coefficient of variation in \% (second line) of Blitum virgatum populations for each of the 24 observed character; percentage of the interpopulation variation in the overall morphological variation for each character $S S b(\%)$, and p-values.

\begin{tabular}{|c|c|c|c|c|c|c|c|c|c|c|}
\hline \multirow{2}{*}{$\begin{array}{c}\text { Cha } \\
\text { racter } \\
\text { num } \\
\text { ber }\end{array}$} & \multicolumn{8}{|c|}{ Population } & \multirow[b]{2}{*}{$\mathrm{SSb}$} & \multirow[b]{2}{*}{$\mathrm{p}$} \\
\hline & 77 & 78 & 116 & 118 & 119 & 117 & 120 & 37 & & \\
\hline \multirow[t]{2}{*}{1} & 46,28 & 31,03 & 49,83 & 46,56 & 45,11 & 42,18 & 37,54 & 38,53 & & \\
\hline & 16,10 & 23,67 & 28,13 & 23,67 & 33,11 & 29,05 & 26,97 & 23,58 & 41,41 & 0,0259 \\
\hline \multirow[t]{2}{*}{2} & 3,92 & 3,79 & 4,03 & 4,71 & 3,96 & 4,11 & 4,00 & 4,28 & & \\
\hline & 11,87 & 9,94 & 11,60 & 20,18 & 15,17 & 21,99 & 20,88 & 20,63 & 27,70 & 0,0168 \\
\hline \multirow[t]{2}{*}{3} & 1,99 & 2,19 & 2,09 & 2,58 & 2,43 & 2,12 & 2,21 & 2,28 & & \\
\hline & 16,80 & 20,64 & 13,26 & 32,44 & 21,86 & 34,27 & 26,87 & 31,68 & 45,73 & 0,0279 \\
\hline \multirow[t]{2}{*}{4} & 2,04 & 1,75 & 1,98 & 1,93 & 1,65 & 2,05 & 1,95 & 2,05 & & \\
\hline & 25,50 & 16,57 & 16,70 & 26,42 & 14,55 & 10,55 & 47,70 & 26,83 & 39,56 & 0,0258 \\
\hline \multirow[t]{2}{*}{5} & 2,08 & 1,87 & 2,36 & 2,49 & 1,96 & 2,37 & 2,93 & 3,23 & & \\
\hline & 23,54 & 27,99 & 27,36 & 25,87 & 19,35 & 32,06 & 35,21 & 35,26 & 53,99 & 0,0243 \\
\hline \multirow[t]{2}{*}{6} & 2,25 & 1,76 & 1,23 & 1,83 & 1,21 & 1,50 & 1,15 & 1,32 & & \\
\hline & 10,95 & 25,08 & 39,20 & 30,53 & 25,06 & 30,44 & 31,95 & 41,99 & 51,38 & 0,0249 \\
\hline \multirow[t]{2}{*}{7} & 0,64 & 0,42 & 0,39 & 0,54 & 0,45 & 0,47 & 0,41 & 0,47 & & \\
\hline & 10,63 & 15,82 & 17,63 & 29,01 & 23,69 & 32,79 & 28,89 & 51,13 & 51,92 & 0,0162 \\
\hline \multirow[t]{2}{*}{8} & 4,74 & 4,26 & 3,28 & 3,52 & 2,73 & 3,88 & 2,90 & 2,94 & & \\
\hline & 30,60 & 29,34 & 39,94 & 39,49 & 21,25 & 15,40 & 26,55 & 33,67 & 58,94 & 0,0247 \\
\hline \multirow[t]{2}{*}{9} & 0,64 & 0,40 & 0,46 & 0,53 & 0,42 & 0,50 & 0,48 & 0,48 & & \\
\hline & 15,94 & 34,13 & 20,81 & 15,75 & 20,76 & 17,99 & 17,14 & 20,76 & 84,77 & 0,0187 \\
\hline \multirow[t]{2}{*}{10} & 20,02 & 25,37 & 33,97 & 35,31 & 30,78 & 34,65 & 33,04 & 35,83 & & \\
\hline & 20,02 & 27,14 & 20,51 & 28,24 & 25,47 & 32,69 & 28,97 & 25,29 & 59,23 & 0,0442 \\
\hline \multirow[t]{2}{*}{11} & 0,00 & 0,00 & 0,00 & 0,00 & 0,00 & 0,00 & 0,00 & 0,00 & & \\
\hline & 0,00 & 0,00 & 0,00 & 0,00 & 0,00 & 0,00 & 0,00 & 0,00 & 0,00 & 0,0000 \\
\hline \multirow[t]{2}{*}{12} & 1,13 & 0,91 & 0,92 & 0,91 & 0,87 & 0,89 & 0,89 & 0,88 & & \\
\hline & 7,55 & 10,42 & 11,20 & 8,34 & 10,94 & 8,94 & 10,99 & 9,27 & 60,30 & 0,0249 \\
\hline \multirow[t]{2}{*}{13} & 1,03 & 0,92 & 1,02 & 0,98 & 0,99 & 0,96 & 0,98 & 0,87 & & \\
\hline & 8,24 & 10,13 & 10,10 & 10,85 & 12,42 & 19,20 & 14,03 & 8,99 & 44,22 & 0,0152 \\
\hline \multirow[t]{2}{*}{14} & 0,45 & 0,38 & 0,43 & 0,41 & 0,42 & 0,39 & 0,41 & 0,37 & & \\
\hline & 11,25 & 15,09 & 16,21 & 17,67 & 19,17 & 19,15 & 18,78 & 13,08 & 56,21 & 0,0198 \\
\hline \multirow[t]{2}{*}{15} & 0,91 & 0,83 & 0,82 & 0,86 & 0,79 & 0,88 & 0,81 & 0,78 & & \\
\hline & 9,44 & 10,97 & 12,89 & 13,42 & 10,42 & 13,38 & 11,25 & 8,06 & 57,22 & 0,0188 \\
\hline 16 & 0,45 & 0,36 & 0,38 & 0,42 & 0,41 & 0,39 & 0,42 & 0,31 & & \\
\hline & 11,37 & 13,84 & 18,54 & 15,98 & 12,30 & 17,97 & 17,92 & 11,03 & 36,46 & 0,0193 \\
\hline 17 & 1,03 & 1,14 & 0,98 & 0,99 & 0,96 & 0,95 & 0,97 & 0,98 & & \\
\hline & 7,30 & 11,77 & 6,02 & 6,91 & 7,10 & 9,61 & 6,84 & 11,04 & 51,64 & 0,0048 \\
\hline 18 & 0,91 & 0,81 & 0,87 & 0,82 & 0,79 & 0,82 & 0,80 & 0,88 & & \\
\hline & 7,18 & 9,91 & 9,62 & 7,93 & 7,69 & 8,69 & 9,85 & 13,14 & 63,11 & 0,0064 \\
\hline 19 & 1,13 & 1,51 & 1,14 & 1,22 & 1,21 & 1,17 & 1,22 & 1,14 & & \\
\hline & 10,62 & 4,24 & 12,28 & 10,65 & 10,65 & 10,26 & 9,84 & 17,54 & 59,72 & 0,0097 \\
\hline 20 & 0,60 & 0,50 & 0,57 & 0,54 & 0,55 & 0,54 & 0,53 & 0,51 & & \\
\hline & 8,36 & 14,86 & 10,45 & 10,43 & 9,25 & 10,49 & 8,79 & 8,46 & 42,75 & 0,0084 \\
\hline 21 & 1,23 & 1,15 & 1,14 & 1,19 & 1,17 & 1,19 & 1,16 & 1,15 & & \\
\hline & 7,85 & 8,80 & 7,15 & 9,08 & 8,81 & 9,49 & 7,71 & 5,45 & 57,60 & 0,0068 \\
\hline 22 & 1,17 & 1,02 & 0,96 & 1,07 & 1,06 & 1,05 & 1,01 & 0,94 & & \\
\hline & 6,51 & 7,11 & 7,61 & 11,21 & 10,68 & 9,06 & 8,47 & 6,00 & 59,71 & 0,0137 \\
\hline 23 & 1,06 & 1,12 & 1,20 & 1,12 & 1,11 & 1,14 & 1,17 & 1,23 & & \\
\hline & 6,43 & 8,90 & 8,30 & 9,82 & 11,71 & 8,77 & 11,10 & 5,70 & 54,82 & 0,0158 \\
\hline 24 & 0,79 & 0,73 & 0,74 & 0,70 & 0,74 & 0,73 & 0,76 & 0,65 & & \\
\hline & 7,05 & 9,61 & 11,55 & 13,31 & 11,00 & 8,77 & 8,88 & 7,08 & 40,10 & 0,0184 \\
\hline
\end{tabular}


GROZEVA N., et al.

Unweighted pair-group average

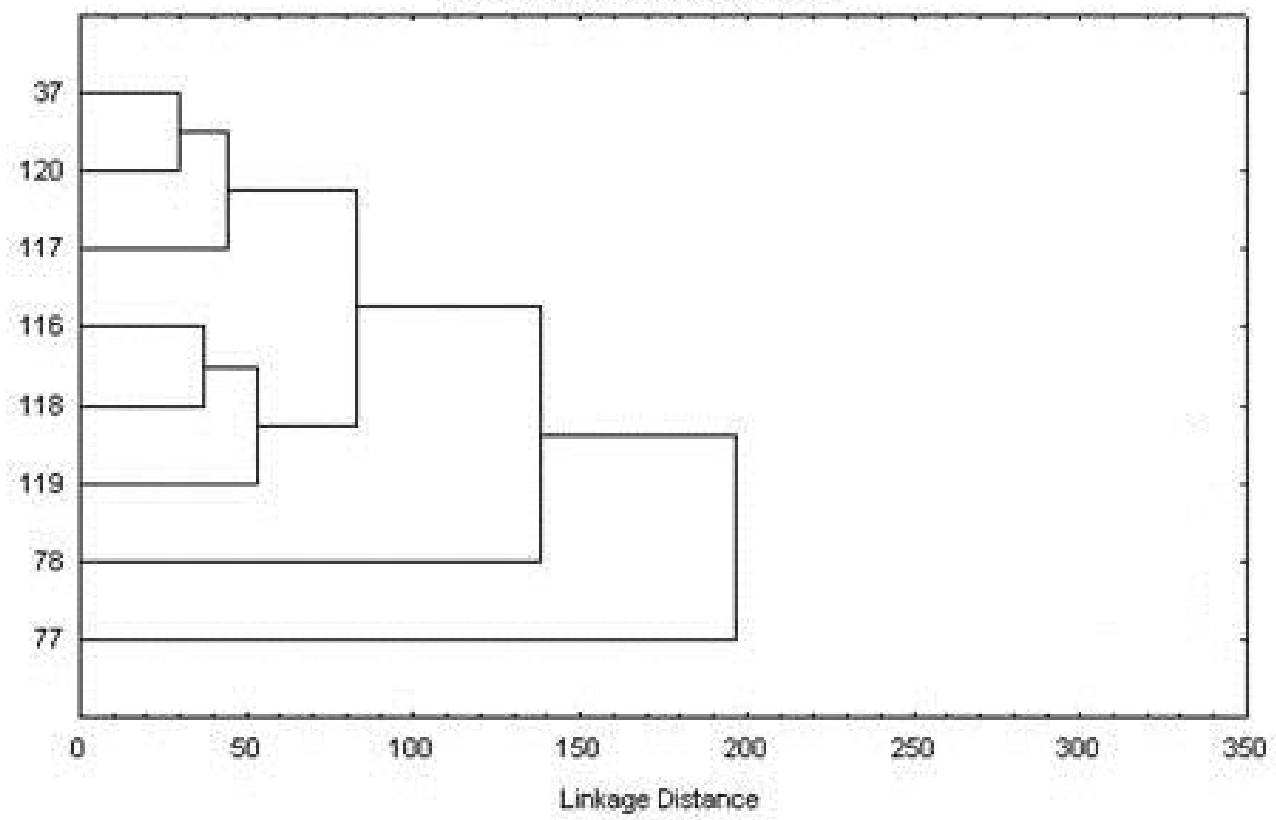

Figure 2. Dendrogram of the hierarchical cluster analysis of the studied populations of Blitum virgatum.
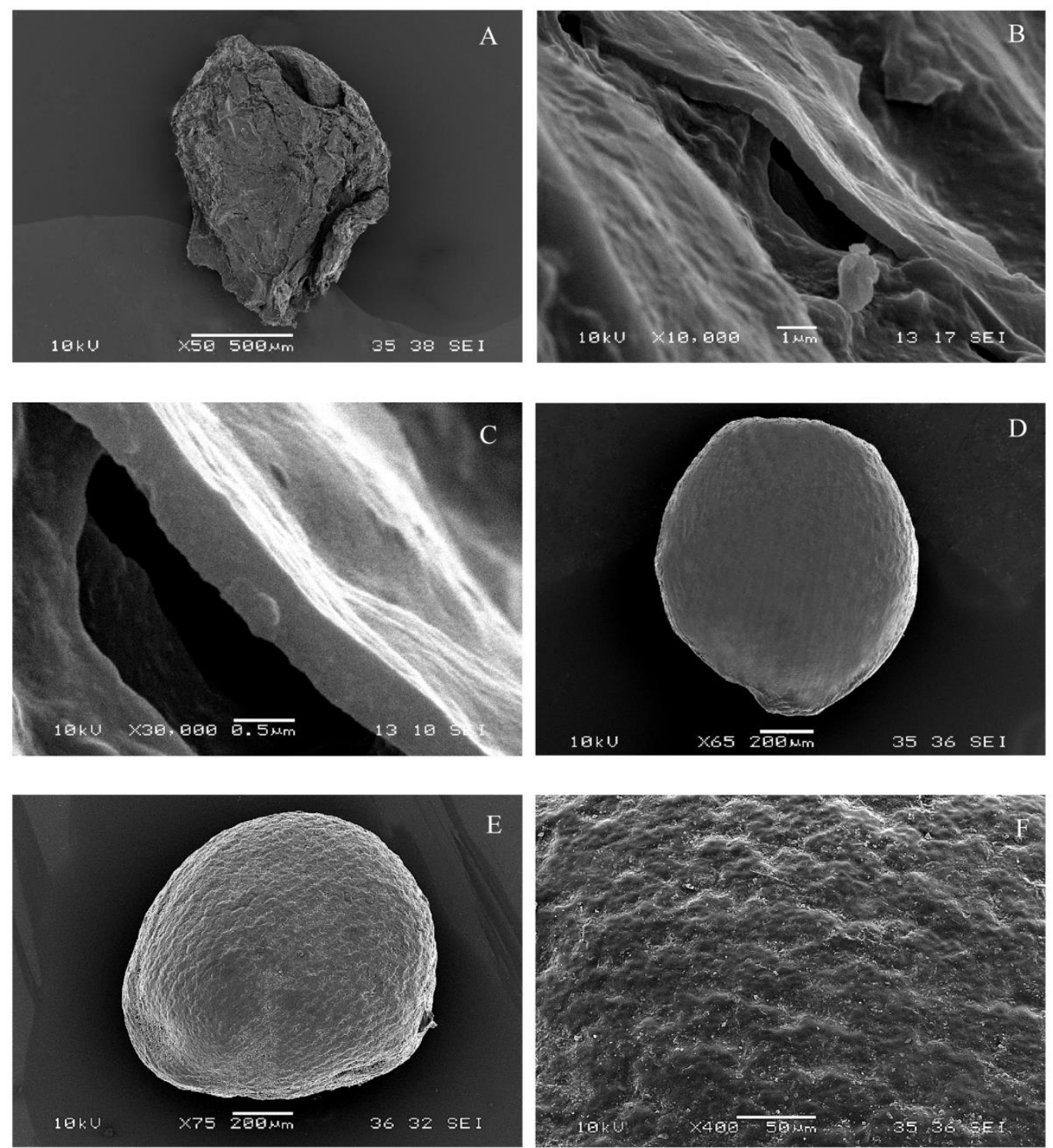

Figure 3. Scanning electron micrographs of Blitum virgatum: A - flower, B-C - pericarp, D-E - view of a seed from both sides, $\mathrm{F}$ - seed surface. 
The hierarchical clustering of the studied populations is based on the similarities of the complex of morphological quantitative traits. As shown in the dendrogram produced by the WPGA clustering algorithm (Figure 2), the first conditionally formed group comprise 3 populations with identical karyotypes - 37 and 120 from Tundzha Hilly Country, and 117 from Belasitsa Mt. The observed high similarity between the first two populations (Table 3) is in accordance with their geographical proximity.
The second group consist of the three populations from the Rhodope Mts - 116, 118, 119 , for which besides the established identity in the karyotypes, similarity in the environmental conditions is also observed.

The populations 77, from the Central Balkan Range, and 78, from the Rila Mt, differ one from another as well as from the conditionally formed groups. This dissimilarity is associated with the different ecological conditions, in particular with the populations' belonging to remote floristic regions.

Table 3. Euclidean distances between the pairs of populations of Blitum virgatum based on 24 characters.

\begin{tabular}{crrrrrrrrr}
\hline & \multicolumn{10}{c}{ Population } \\
Population & $\mathbf{3 7}$ & $\mathbf{7 7}$ & $\mathbf{7 8}$ & $\mathbf{1 1 6}$ & $\mathbf{1 1 7}$ & $\mathbf{1 1 8}$ & $\mathbf{1 1 9}$ & $\mathbf{1 2 0}$ \\
& & & & & & & & \\
\hline $\mathbf{3 7}$ & 0 & 207 & 119 & 115 & 40 & 81 & 84 & 30 \\
$\mathbf{7 7}$ & 207 & 0 & 186 & 201 & 209 & 203 & 208 & 222 \\
$\mathbf{7 8}$ & 119 & 186 & 0 & 189 & 131 & 168 & 133 & 90 \\
$\mathbf{1 1 6}$ & 115 & 201 & 189 & 0 & 77 & 37 & 57 & 123 \\
$\mathbf{1 7}$ & 40 & 209 & 131 & 77 & 0 & 45 & 49 & 50 \\
$\mathbf{1 1 8}$ & 81 & 203 & 168 & 37 & 45 & 0 & 49 & 94 \\
$\mathbf{1 1 9}$ & 84 & 208 & 133 & 57 & 49 & 49 & 0 & 80 \\
$\mathbf{1 2 0}$ & 30 & 222 & 90 & 123 & 50 & 94 & 80 & 0 \\
\hline
\end{tabular}

The population 77 from the Central Balkan Range differs the most (Table 3). Its specimens have larger upper leaves (Table 2). The other vegetative and generative traits are within the norms; however there are individual features that are similar to the characters of some of the other populations. The observed variation is probably due to the medium (compared to all other) altitude (Table 1).

The results from the univariate ANOVA showed that for 15 out of 24 studied quantitative traits the interpopulation variability is more strongly expressed, particularly by the high values of the upper leaf petiole length (Table 2). In 8 of the traits plant height; basal leaves length, width and length/width ratio; perianth lobes length of bisexual flower; perianth lobes length of female flower; seed and fruit thickness - the intrapopulation variability is dominant. The established higher interpopulation variability is influenced by the differences in the altitude and the communities' composition of the populations. The smaller intrapopulation variability is consistent with the smaller area and population size, as well as with the identical ecological conditions of the area.

The observed variability is probably a consequence of the weak competitiveness of the species, especially in the beginning of its vegetation, when specimens located in close proximity to the cereal species or to perennial species of other families with well-developed root system are visibly with depressed and slow growth.

\section{Ecology}

Asectation species in antropophytes or ruderal communities dominated by Urtica dioica L., Agropyron repens (L.) P.Beauv., Datura stramonium L., Solanum nigrum L., Amaranthus retroflexus L. and others in foothill and mountain areas. It is also spread in open degraded areas in the flat zone. It usually forms small in number, rarely multiple populations on different types of soils on sloping or flat areas at an altitude of 150 to $1500 \mathrm{~m}$

\section{CONCLUSION}

The conducted study reveals that the chromosome number in all Bulgarian populations of Blitum virgatum is $2 n=18$ and the karyotype is rather symmetric (14m:4sm; 14m:2m-SAT:2sm; 14m:2m-SAT:2sm-SAT). There is a correlation between the karyotype variability and the level of the interpopulation and intrapopulation differences on one hand, and the ecological conditions of the respective habitats on the other. The results of the present complete population research of Blitum virgatum confirm the findings from our previous research $(24,25,26)$ on the species from Chenopodiaceae, namely that the 
GROZEVA N., et al.

vegetative traits are more variable than the generative ones (Table 3). The traits characterizing the basal leaf petiole length and inflorescence length have the highest variability. The least variable are the ones characterizing the seed and the fruit. The main source of phenotype variation in all population is the interpopulation variation. The recorded higher intrapopulation variability in 8 of the characters: stem height; length and width of the leaf lamina of the basal leaves and the ratio between them; perianth lobes length of bisexual flower; perianth lobes width of female flower; seed and fruit thickness, is probably due to the low competitiveness of the species, especially in the beginning of the vegetation. Interpopulation differences are influenced by the differences in karyotypes, environmental conditions and composition of communities .

Among the 8 studied populations the one from Central Balkan Range has the most pronounced interpopulation differences. Its specimens are characterized by the largest upper leaves.

Blitum virgatum is a ruderal plant and that implies its wide distribution. Considering the fact that the species is an annual and medicinal plant, and usually forms populations small in number, its conservation in Bulgaria is only possible through proper exploitation of its habitats.

\section{REFERENCES}

1. Markova, M., Chenopodium L. In: Yordanov, D. (ed.), Flora of the People's Republic Bulgaria, Vol. 3, pp. 527-541 (in Bulgarian). Aedibus Academiae Scientiarum Bulgaricae, Serdicae, 1966.

2. Akeroyd, J. Chenopodium L. In: Tutin, T.G. \& al. (eds), Flora Europaea. Ed. 2., Vol. 1, pp. 11-114. Cambridge Univ. Press., Cambridge, 1993.

3. Uotila, P. \& Tan, K. Chenopodium L. In: Strid, A. \& Tan, Kit (eds), Flora Hellenica. Vol. 1, pp. 112-121. Koeltz Scientific Books, Königstein, 1997.

4. Uotila, P. Chenopodium L. In: Jonsell, B. (ed.), Flora Nordica. Vol. 2, pp. 4-31. N. A. S., Stockholm, 2001.

5. Assyov, B. \& Petrova, A. (eds). Conspectus of the Bulgarian Vascular Flora. Distribution Maps and Floristic Elements, Fourth revised and enlarged edition. Bulgarian Biodiversity Foundation, Sofia. (Bg), 2012.

6. Siraj, A., Asghar A., Hanifa B., Altaf, A.D., Zabta K.S. Ethnobotanical studies on some medicinal plants of Booni valley, district Chitral Pakistan. Pak J. Weed Sci. Res. 12(3): 183-190, 2006.
7. Serteser, A., Kargio, M., Gök, V., Ba., Y, Özcan, M.M, Arslan. Antioxidant properties of some plants growing wild in Turkey. Grasas Y Aceites, 60(2): 147-154, 2009.

8. Rajaei, P., Mohamadi, N. Ethnobotanical Study of Medicinal Plants of Hezar Mountain allocated in South East of Iran. Iranian J. of Pharm. Research, 11(4): 11531167, 2012.

9. Medicinal Plants Act,. Darzhaven vestnik, 29/07.04.2000.

http//www.moew.government.bg/recent_d oc/.../Le4ebnirastAct.doc (Bg).

10.Kokanova-Nedialkova, Z., Bücherl, D., Nikolov, S., Heilmann, J., Nedialkov, P.T. Flavonol glycosides from Chenopodium foliosum Asch. Phytochemistry letters, 4(3): 367-371, 2011.

11.Nedialkov, P., Kokanova-Nedialkova, Z., Bücherl, D., Momekov, G., Heilmann, J. Nikolov, S. 30-normedicagenic acid glycosides from Chenopodium foliosum. Nat. Prod. Commun., 7(11): 1419-1422, 2012.

12. Van Loon, I, Van Setten, A. Reports. In: Löve, A (ed.). Chromosome number reports, LIX. Taxon, 27: 56-60, 1982.

13.Grozeva, N., Stoeva, M. Mediterranean chromosome number reports 16 (14661472). Fl. Medit. 16: 400-408, 2006.

14.Grozeva, N. Chenopodium pumilio (Chenopodiaceae): a new species to the Bulgarian flora. Phytol. Balcan., 13(3): 331-334, 2007.

15.Grif, V. G., Agapova, N., D. The methods of description of plant karyotypes (in Russian). Botanichesky Zhurnal 71, 550553, 1986.

16. Kawatani, T, Ohno, T. Chromosome numbers of genus Chenopodium. 2. Japanese J. of Genetics, 31: 15-17, 1956.

17.Fedorov, A. N. (ed.). Chromosome Numbers of Flowering plants. Leningrad, 1969.

18. Magulaev, A. J.. The chromosome numbers of flowering plants of the Northern Caucasus. Fl. North. Caucasus, 2: 51-62, 1976.

19.Dvořák, F., Dadakova, B., Grüll, F. Studies of the morpholofy of chromosomes of some selected species. Folia Geobot. Phytotax., 12: 343-375, 1977.

20.Schwarzová, T. Chromosome numbers of some species of the genus Chenopodium L. from localities in Czechoslovakia. Acta Fac. Rerum Nat. Univ. Comenianae, Bot. 33: 37-40, 1986.

21.Lomonosova, M. N., Krasnikov, A.A. Chromosome numbers in some species of 
genus Chenopodium (Chenopodiaceae) of the flora of Siberia. Bot. Žhurn. (Moscow \& Leningrad) 79(3): 124-125, 1994.

22.Krasnikov, A.A. Karyological study of the Tuva Republic flora: a summary. Turczaninowia 7(2): 82-95, 2004.

23.Lomonosova, M. N., Krasnikova S.A, Krasnikov, A.A., Ebel, A.L., Rudaja, N.A. Chromosome numbers of the family members Chenopodiaceae representatives from Mongolia and Kazakhstan. Bot. Žhurn. (Moscow \& Leningrad) 88(8): 113115, 2003.

24.Grozeva, N., Cvetanova, Y: Variability among the populations of two species from genus Chenopodium. Proceedings 7 Scientific Conference of Ekology and Health. Academic Publishing House of Agrarian University, Plovdiv, 135-140, 2008.

25.Grozeva, N., Cvetanova, Y. Chenopodium bonus-henricus (Perennial goosefoot) in Bulgaria. I. Population variability. Trakia J. of Sci. 9, 1-7, 2011.

26. Grozeva, N., Cvetanova, Y. Karyological and morphological variations within the genus Dysphania (Chenopodiaceae) in Bulgaria. Acta Bot. Croat., 72(1): 49-69, 2013. 